\title{
Relationship between Soil Salinity and Physico-chemical Properties of Paddy Field Soils of Jhilwanja Union, Cox’s Bazar, Bangladesh
}

\author{
Nazmul Hossain ${ }^{1}$, Muhammad Muhibbullah ${ }^{2}$, Kazi Md. Barkat Ali ${ }^{2} \&$ Morshed Hossan Molla ${ }^{2}$ \\ ${ }^{1}$ Department of Soil Science, University of Chittagong, Chittagong, Bangladesh \\ ${ }^{2}$ Department of Geography and Environmental Studies, University of Chittagong, Chittagong, Bangladesh \\ Correspondence: Muhammad Muhibbullah, Department of Geography and Environmental Studies, University of \\ Chittagong, Chittagong-4331, Bangladesh. Tel: 880-119-518-0628. Fax: 880-031-260-6014. E-mail: \\ md_muhibbullah@yahoo.com
}

Received: June 22, 2015 Accepted: July 29, 2015 Online Published: September 15, 2015

doi:10.5539/jas.v7n10p166 URL: http://dx.doi.org/10.5539/jas.v7n10p166

\begin{abstract}
This study attempts to examine the relationship between soil salinity and physico-chemical properties of paddy field soils of Jhilwanja union in Cox's Bazar, Bangladesh. Data were analyzed by the help of Statistical Package for the Social Sciences (SPSS: version-18) and study area map was prepared by Arc GIS 9.3 software. Present investigation reveals that soil textural class ranged from sandy to loam, a mean bulk density $1.58 \mathrm{~g} / \mathrm{cm}^{3}$, and high soil temperature $(M=31.55)$. Soils were moderately acidic to basic and soil salinity $(\mathrm{EC})$ content comes under low to medium $($ minimum $=3.10 \mathrm{dS} / \mathrm{m}$, maximum $=7.24 \mathrm{dS} / \mathrm{m}$ ) range. The organic matter level exhibited absolutely lower $(M=0.75)$ than good agricultural soil. Soils of the area represents low in total $\mathrm{N}(M=0.08)$, very low in total $\mathrm{P}$ content $(M=0.06)$, exchangeable $\mathrm{Ca}(M=0.0009)$ were too low and lower content of exchangeable $\mathrm{Mg}(M=0.26)$, but high level of exchangeable $\mathrm{K}(M=0.57)$ content. Simple regression analysis showed that there was a significant effect of soil salinity on soil $\mathrm{pH}$, soil temperature, $\mathrm{OM}$, total $\mathrm{N}$, total $\mathrm{P}$, exchangeable $\mathrm{K}$ and $\mathrm{Mg}$. Repairing coastal embankment (rubber dam), cultivating native high yielding variety, using organic fertilizer, implementing Integrated Soil Nutrient Management (ISNM) and adapting Integrated Coastal Zone Management (ICZM) can increase crop production and soil fertility level in study area.
\end{abstract}

Keywords: soil salinity, physico-chemical properties, paddy field, Jhilwanja union Cox's Bazar, Bangladesh

\section{Introduction}

A number of environmental issues and problems are hindering the development of coastal livelihood of Bangladesh. Salinity is one of them, which is expected to aggravate by climate change and sea level rise and eventually affect food production. Bangladesh has $147,570 \mathrm{~km}^{2}$ land area that includes $710 \mathrm{~km}$ coastal line along the Bay of Bengal (Bangladesh Bureau of Statistics [BBS], 2003). Agriculture is the major sector of national economy. Total coastal zone has $47,201 \mathrm{~km}^{2}$ areas (Islam, Razzaque, Rahman, \& Karim, 2004). The cultivable land covers $59 \%$ in which $16 \%$ of area is under rice cultivation (Ahmed, 2011). Salinity has serious negative impacts on agriculture (Hossain, 2009). In Bangladesh about 0.883 million hectares of the arable lands, which constitutes about 52.8 percent of the net cultivable area in 64 Upazilas of 13 districts, are affected by varying degrees of soil salinity (Karim, Hossain, \& Ahmed, 1990). A recent study indicates that the salinity affected area has increased from 8,330 $\mathrm{km}^{2}$ in 1973 to $10,560 \mathrm{~km}^{2}$ in 2009 (Soil Resource Development Institute [SRDI], 2010). Tidal flooding occurs during wet season (June-October), direct inundation by saline water and upward on lateral movement of saline ground water during the dry season (November-May) (Haque, 2006). In addition, cyclone and tidal surge is accelerating this problem (Abedin, 2010). In the coastal areas of Bangladesh, saline water is used for irrigation which reduces the growth of most agricultural crops (Murtaza, Ghafoor, \& Qadir, 2006). Salinization is one of the most serious types of land degradation as well as and a major obstacle to the optimal utilization of land resources (Liang, Si, Nikolic, Peng, \& Chen, 2005). Approximately 952 million ha are estimated to be salt affected and this area is increasing year after year all over the world (Wang, Wu, Xie, Liu, \& Cui, 2012). Soil salinity (electrical conductivity: $\mathrm{EC}>4 \mathrm{dS} \mathrm{m}^{-1}$ ) is a major abiotic stress which limits plant growth and development, causing yield loss in crop species (Qadir, Oster, Schubert, Noble, \& Sahrawat, 2007). Salt-affected soils are identified by excessive levels of water-soluble salts, especially sodium chloride $(\mathrm{NaCl})$ (Tanji, 2002). Salinity is causing decline in soil productivity and crop yield which results in severe degradation 
of bio-environment and ecology (Hoque, Saika, Sarder, \& Biswas, 2013) as well as responsible for low cropping intensity in coastal area (Rahman \& Ahsan, 2001).

Rice (Oryza sativa L. spp. indica) is one of the five main carbohydrate crops responsible for feeding the world's population including Asian countries and more than 3 billion people which comprises $50 \%-80 \%$ of their daily calorie intake from rice (Khush, 2005). Rice has previously been reported as salt susceptible in both seedling (Munns \&Tester, 2008), and reproductive stages (Moradi \& Ismail, 2007) leading to a reduction of more than $50 \%$ in yield when exposed to $6.65 \mathrm{dSm}^{-1}$ ECe (Zeng \& Shannon, 2000). Ali (2005) investigated the loss of rice production in a village of Satkhira district (a salinity affected area) where loss of rice production was $69 \%$ in the year of 1985 to 2003.

Cox's Bazar district is vulnerable to cyclones, tidal surges, tidal \& flash flood, earthquake and other natural calamities (BBS, 2001). From the year 1960 to 1995, seven major cyclones hit whole district. The most devastating cyclone of the last century hit Cox's Bazar in November 1970. In 1991, another deadly cyclone hit there (United Nations Office for Project Services [UNOPS], 2008). The paddy field also become saline because it contact with the sea water and continues to be inundated during high tides and ingress of sea water through river \& creeks in Cox's Bazar. As a result salinization process accelerates and reducing soil fertility. Farmers are changing agricultural practices and reducing crop cultivation. The objectives of this study were to determine the level of soil salinity and assessing current soil fertility status of paddy fields and recommend some measures to reduce salinization process to improve soil fertility status in Jhilwanja union of Cox's Bazar district of Bangladesh. Intensive researches on soil salinity have reported the adverse effects of salinity on the physical and chemical properties of soils and on plant growth and yield (Kahlown \& Azam, 2003). But there is limited research on the relationship between soil salinity and physico-chemical properties of paddy field soils and prediction their effects. This study attempted to focus to fill that research gap.

\section{Study Area}

Cox's Bazar is a coastal district and natural combination of hill and sea. Cox's Bazar Sadar has 10 Unions, 140 villages and 40 Mahallas, Jhilwanja union is one of them (District Statistics, 2011; BBS, 2013). Jhilwanja union lies between $21^{\circ} 28^{\prime}$ and $21^{\circ} 30^{\prime} \mathrm{N}$ latitudes and between $91^{\circ} 58^{\prime}$ and $92^{\circ} 02^{\prime}$ E longitudes (Map 1). Population; total population of Jhilwanja union is 79,203 and population density $2,579 / \mathrm{km}^{2}$. Topography; Total area of Jhilwanja union is $2913 \mathrm{ha}$ and hilly forest area cover 1515.38 ha (25\%), high land $10 \%$, medium high land 50\% and medium low land $15 \%$ of total area of this union. Soil characteristics: soil pH ranges 4.5-5.7, soil texture is silt, soil salinity ranges $0-12 \mathrm{dS} / \mathrm{m}$, soil pattern is complex due to local differences in sand, silt and clay contents of the underlying sedimentary rock, moderately fertile soil with low organic matter content, moisture holding capacity is poor and moderately suitable for agricultural crops due to hilly forest land. Agricultural activities; about $30 \%$ people are directly or indirectly depends on agriculture and they cultivate paddy, potato, pulse, onion, garlic, ginger, betel leaf, betel nut, wheat, sugarcane, ground nut, tobacco, rubber and vegetables, (Municipal Manuel, 2013 ; BBS, 2001).

\section{Methods}

\subsection{Soil Sample Collection}

Spot method and random sampling techniques were used for sample collection from different paddy fields. Soil samples were collected from $0-15 \mathrm{~cm}$ depth. A total number of 11 samples were collected to determine surface soil salinity and fertility status. Samples were collected and analyzed from November 2015 to April 2015. Global Positioning System (GPS) was used to record the absolute positions of collected samples (Table 1). For soil samples, a transparent polythene bags were used to preserve the samples and each bag was labelled. Samples were dried in laboratory at room temperature $\left(25^{\circ} \mathrm{C}\right)$ for 20 days and then ground. The ground samples were then sieved through a 20 -mesh sieve $(<2 \mathrm{~mm}$ diameter) to make the samples suitable for chemical analyses (Hesse, 1971; Petersen, 2002). The labeled samples were analyzed in the environmental lab of the Department of Geography and Environmental Studies and Department of Soil Science, University of Chittagong, Bangladesh. 
Table 1. Sampling location of the study area

\begin{tabular}{llll}
\hline Site No. & Sample no. & Sampling Station & GPS value \\
\hline Site 1 & S1 & Kolatoli Hill (Valley area) & $21^{\circ} 24^{\prime} 50.9^{\prime \prime}-91^{\circ} 59^{\prime} 13.2^{\prime \prime}$ \\
Site 2 & S2 & South Kolatoli Hill (Valley area) & $21^{\circ} 24^{\prime} 22.2^{\prime \prime}-91^{\circ} 59^{\prime} 30.7^{\prime \prime}$ \\
Site 3 & S3 & Chondrica (Valley area) & $21^{\circ} 24^{\prime} 50.8^{\prime \prime}-91^{\circ} 59^{\prime} 18.5^{\prime \prime}$ \\
Site 4 & S4 & Police Line (Valley area) & $21^{\circ} 25^{\prime} 09.3^{\prime \prime}-91^{\circ} 59^{\prime} 31.3^{\prime \prime}$ \\
Site 5 & S5 & College Area (Plain area) & $21^{\circ} 25^{\prime} 23.4^{\prime \prime}-92^{\circ} 01^{\prime} 2.5^{\prime \prime}$ \\
Site 6 & S6 & Janar Gona (Plain area) & $21^{\circ} 25^{\prime} 40.4^{\prime \prime}-92^{\circ} 01^{\prime} 71^{\prime \prime}$ \\
Site 7 & S7 & Chandro Pahar (Plain area) & $21^{\circ} 25^{\prime} 42.5^{\prime \prime}-92^{\circ} 01^{\prime} 9.9^{\prime \prime}$ \\
Site 8 & S8 & South Rubber Dam (Plain area) & $21^{\circ} 26^{\prime} 2.6^{\prime \prime}-92^{\circ} 01^{\prime} 10.7^{\prime \prime}$ \\
Site 9 & S9 & North Rubber Dam (Plain area) & $21^{\circ} 26^{\prime} 7.7^{\prime \prime}-92^{\circ} 01^{\prime} 12.8^{\prime \prime}$ \\
Site 10 & S10 & Khurulia (Plain area) & $21^{\circ} 25^{\prime} 52.3^{\prime \prime}-92^{\circ} 01^{\prime} 44.6^{\prime \prime}$ \\
Site 11 & S11 & Link Road (Plain area) & $21^{\circ} 25^{\prime} 6.6^{\prime \prime}-92^{\circ} 01^{\prime} 38.8^{\prime \prime}$ \\
\hline
\end{tabular}

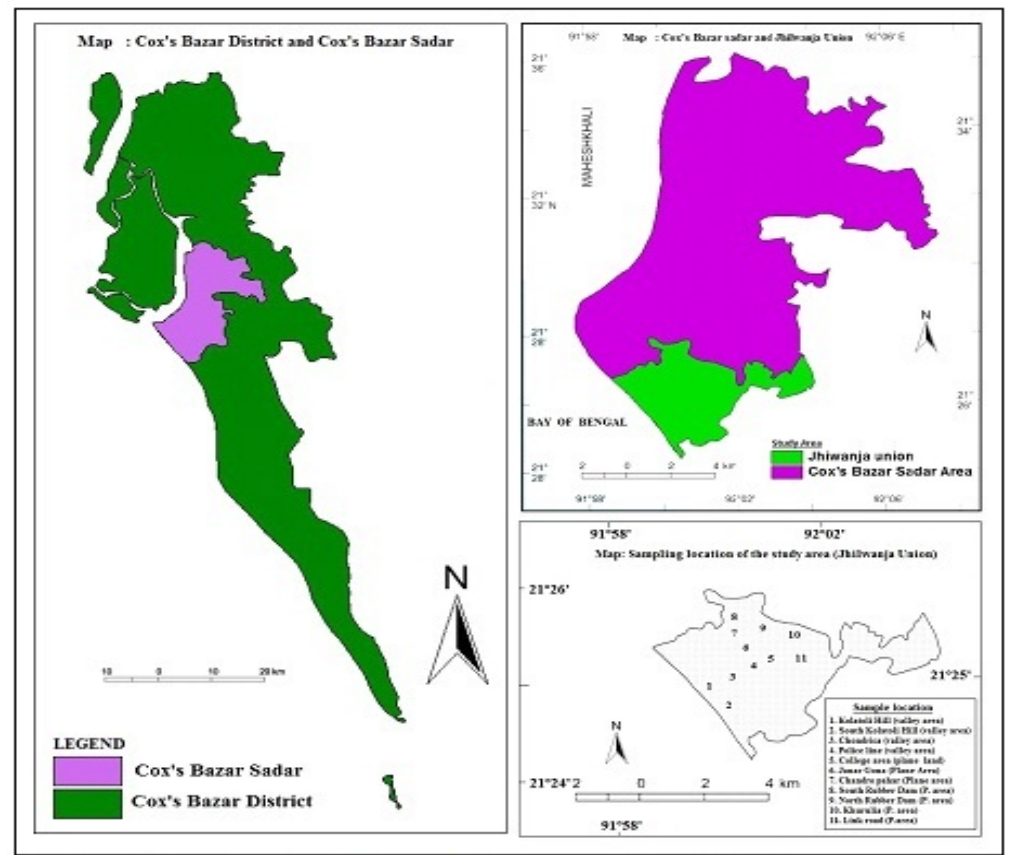

Figure 1. Location of the study area (Cox's Bazar District, Cox's Bazar Sadar and Jhilwanja Union)

Source: Base map was collected from Cox's Bazar Municipility (2013) and LGED (2003).

\subsection{Soil Analysis}

The particle size distribution was determined by hydrometer method of Day (1965). Percentages of sand ( $>50$ $\mu \mathrm{m})$, silt $(2$ to $50 \mu \mathrm{m})$ and clay $(<2 \mu \mathrm{m})$ were determined and used to identify the textural class from the textural triangle. This standard soil textural triangle was devised by the United States Department of Agriculture (USDA) (Soil Survey Staff, 1951). Bulk density was determined by Saxton, Rawls, Romberger, and Papendick (1986) adapted by the Canadian soil texture triangle by Pedosphere.ca. Temperature $\left({ }^{\circ} \mathrm{C}\right)$ was determined by the thermometer. Soil $\mathrm{pH}$ was determined by glass electrode $\mathrm{pH}$ meter as described by (Jackson, 1962) with soil water ratios of 1:2.5. Soil Electrical conductivity (EC) was measured by using a conductivity meter (Rhoades, 1982), and Organic carbon was determined by wet-oxidation method of Walkley and Black (1934) as modified by Allison (1965) was used to determine organic carbon. The organic matter was obtained by multiplying the content of organic carbon by Van Bemmelen, factor of 1.73 (Page, Miller, \& Keeney, 1982). Total nitrogen was determined by micro-Kjeldahl digestion by using $\mathrm{CuSO}_{4}-\mathrm{Na}, \mathrm{SO}_{4}$ catalyst mixture was used to determine total 
nitrogen. The ammonia $\left(\mathrm{NH}_{3}\right)$ from the digestion was distilled with $40 \% \mathrm{NaOH}$ into $5 \%$ Boric acid and determined by titrating with $0.001 \mathrm{~N} \mathrm{H}_{2} \mathrm{SO}_{4}$ (Jackson, 1973). Total $\mathrm{P}$ of the soil samples were determined after digestion with nitric acid-perchloric acid (Olsen \& Sommers, 1982; Chintala et al., 2014a). P in the extract was measured colourimetrically by the phospho-vanadomolybdate method (Kitson \& Mellon, 1944; Hanson, 1950). Content of exchangeable Potassium (K), Calcium (Ca) and Magnesium $(\mathrm{Mg})$ of the soil samples were determined after digestion with nitric acid-perchloric acid (Olsen \& Sommers, 1982; Chintala et al., 2014b); and measured by Atomic Absorption Spectrophotometer. Data were analyzed with SPSS 18.0 and Microsoft Office Excel and final map was prepared by Arc GIS 9.3 software.

\section{Results and Discussion}

\subsection{Determination of Physico-chemical Properties of Soil}

The concentrations of soil nutrients (e.g., organic C, N, P, and K) are good indicators of soil quality and productivity because of their favorable effects on the physical, chemical, and biological properties of soil Cao, Jiang, Ying, Zhang, and Han (2011). Saline soils vary widely in their physical and chemical properties as well as hydrology (Ikehashi \& Ponnamperuma, 1978). Following table summarize the selected physico-chemical properties [\% Sand,\% Silt,\% Clay, Bulk Density $\left(\mathrm{g} / \mathrm{cm}^{3}\right)$, Soil Temperature $\left({ }^{\circ} \mathrm{C}\right), \mathrm{pH}, \mathrm{EC}\left(\mathrm{dS} \mathrm{m}^{-1}\right)$, Organic Matter (\%), Total N (\%), Total P (\%), Exchangeable K (\%), Exchangeable Ca (\%), Exchangeable Mg (\%)] of soils from paddy fields of Jhilwanja union of Cox's Bazar, Bangladesh.

Table 2. Descriptive statistics of physico-chemical properties of soil from paddy fields

\begin{tabular}{llllll}
\hline Physico-chemical properties & $\mathbf{N}$ & Minimum & Maximum & $\boldsymbol{M}$ & $\boldsymbol{S D}$ \\
\hline Sand $(\%)$ & 11 & 33.00 & 93.00 & 56.99 & 18.98 \\
Silt (\%) & 11 & 2.00 & 60.00 & 35.68 & 18.03 \\
Clay (\%) & 11 & 5.00 & 10.00 & 7.33 & 1.75 \\
Bulk Density $\left(\mathrm{g} / \mathrm{cm}^{3}\right)$ & 11 & 1.51 & 1.66 & 1.58 & 0.05 \\
Soil Temperature $\left({ }^{\circ} \mathrm{C}\right)$ & 11 & 26.00 & 35.00 & 31.55 & 2.50 \\
Soil pH & 11 & 5.10 & 8.10 & 6.84 & 1.18 \\
EC (dS/m) & 11 & 3.10 & 7.24 & 5.28 & 1.42 \\
O.M (\%) & 11 & 0.22 & 1.32 & 0.75 & 0.31 \\
Total N (\%) & 11 & 0.03 & 0.12 & 0.08 & 0.03 \\
Total P (\%) & 11 & 0.01 & 0.10 & 0.06 & 0.03 \\
Exchangeable K (\%) & 11 & 0.20 & 1.04 & 0.57 & 0.25 \\
Exchangeable Ca (\%) & 11 & .0000 & 0.0037 & 0.0009 & 0.0013 \\
Exchangeable Mg (\%) & 11 & 0.05 & 0.61 & 0.26 & 0.21 \\
\hline
\end{tabular}

Note. The soil analysis is a mean of three replications.

\subsubsection{Soil Texture}

The relative percentage of soil separates (Sand, Silt and Clay) of a given soil is referred to as soil texture. The common textural classes, as recognize by USDA (U.S. Department of Agriculture) are given in equilateral triangles are international equilateral triangles model, (Shukla \& Chandel, 2000). Present investigation shows that, sand content of the soil ranged from 33.00 to $93.00 \%$ with a mean value of $56.99 \%$ (Table 2). Silt content varied from 2.00 to $60.00 \%$ with an average value of $35.68 \%$ and Clay content was found from 5.00 to $10.00 \%$ with a mean of $7.33 \%$ (Table 2). Sand particles were found highest in S1 $(93.00 \%)$ sample and lowest was in S9 (33.00) sample. Maximum value of silt\% was found in S9 sample (60.00\%) and lowest was investigated in S1 (2.00\%). Clay content was highest in S3, S8 \& S11 (10.00\%) and lowest value was found in S1 \& S5 (5.00\%). Textural class of the soils ranged from Sandy to Loam. Sandy soil was found 9.09\% (in S1, valley area soil), Sandy loam 45.45\% [S2, S4, S5, S6 \& S7 (valley area \& plain area)], Silt Loam 27.27\% [S3, S9, \& S10 (valley area and plain area)] and Loam was $18.18 \%$ [S8 \& S11 (plain area)] in study area. Islam, Anusontpornperm, Kheoruenromne, and Thanachit (2014) found most soils had loamy sand to sandy loam texture. Velayutham et al. (1999) found partially similar findings in respect to soil particles percentage in coastal agricultural soils. 


\subsubsection{Bulk Density $\left(\mathrm{g} / \mathrm{cm}^{3}\right)$}

Dry weight of unit volume of soil inclusive of pore spaces is called bulk density. Average density of soil in bulk is $1.5 \mathrm{~g} / \mathrm{cm}^{3}$. Organic soils have low bulk density as compared to mineral soils (Shukla \& Chandel, 2000). Bulk density of the studied soils ranged from 1.51 (S3) to $1.66 \mathrm{~g} / \mathrm{cm}^{3}$ (S1) with a mean value of $1.58 \mathrm{~g} / \mathrm{cm}^{3}$ (Table 2). A normal range of bulk densities for clay is 1.0 to $1.6 \mathrm{~g} / \mathrm{cm}^{3}$ and a normal range for sand is 1.2 to $1.8 \mathrm{~g} / \mathrm{cm}^{3}$ with potential root restriction occurring at $\geq 1.4 \mathrm{~g} / \mathrm{cm}^{3}$ for clay and $\geq 1.6 \mathrm{~g} / \mathrm{cm}^{3}$ for sand Aubertin and Kardos (1965). Islam et al. (2014) found most soils had high bulk density in coastal agricultural soil and influences by soil physical (texture, porosity) and chemical (organic matter, constituent minerals) properties Chaudhari, Ahire, Ahire, Chakravarty, and Maity (2013). In sandy textured soil contains higher bulk density $\left(1.66 \mathrm{~g} / \mathrm{cm}^{3}\right)$ than sandy loam (1.59 to $\left.1.63 \mathrm{~g} / \mathrm{cm}^{3}\right)$, silt loam $\left(1.51\right.$ to $\left.1.59 \mathrm{~g} / \mathrm{cm}^{3}\right)$ and loam $\left(1.53 \mathrm{~g} / \mathrm{cm}^{3}\right)$ textured soil. These results were in confirmatory with the results reported by Chaudhari et al. (2013).

\subsubsection{Soil Temperature $\left({ }^{\circ} \mathrm{C}\right)$}

Soil temperature ranged from $26-35{ }^{\circ} \mathrm{C}(M=31.55)$ and this temperature can adversely effects on rice production in studied area because of extreme temperatures (whether low or high) causes injury to the rice plant. High temperatures are a constraint to rice production and cause a significant yield reduction. When temperatures exceed the optimal for biological processes, crops often respond negatively with a steep decline in net growth and yield (Basak, Ali, Islam, \& Alam, 2009). Hence, the critically low and high temperatures, normally below 20 ${ }^{\circ} \mathrm{C}$ and above $30^{\circ} \mathrm{C}$, vary from one growth stage to another stage Krishnan, Ramakrishnan, Reddy, and Reddy (2011).

\subsubsection{Soil $\mathrm{pH}$}

The activity of microorganisms, plant growth, biochemical breakdown, solubility and absorption of colloids etc. are known through soil pH (Brady \& Weil, 2004). Soil pH is the most important factor in the nutrient available of soils. In most cases, a pH range of 6.0-7.5 is optimum for the adequate availability of nutrients in the soil (Bangladesh Agricultural Research Council [BARC], 2005). Soil $\mathrm{pH}$ of the paddy field was moderately acidic to basic (Table 3) here. Maximum pH content was found 8.10 and minimum 5.10, $(M=6.84)$ (Table 2). Lowest $\mathrm{pH}$ value was found in S1 and highest value was found in S11 sample. It was noticeable that soil $\mathrm{pH}$ was so acidic in valley area (S1) but it gradually increased (basic) towards plain agricultural fields (in S6, S8, S9 \& S10). The classification of soils from study area on the basis of $\mathrm{pH}$ is summarized in Table 3.

Table 3. Classification of soil $\mathrm{pH}$ of the sample according to standard of Boyed et al. (2004)

\begin{tabular}{lll}
\hline pH range & Type & No. of Soil Samples, percentage (\%) and locations \\
\hline Less than 4.0 & Strongly acidic & Nill \\
4.1 to 5.0 & Acidic & Nill \\
5.1 to 6.8 & Moderately acidic & $5,45.45 \%, \mathrm{~S} 1, \mathrm{~S} 2, \mathrm{~S} 3, \mathrm{~S} 4$ \& S7 \\
6.9 to 7.0 & Neutral & $1,9.09 \%, \mathrm{~S} 5$ \\
7.2 to 7.9 & Moderate basic & $2,18.18 \%, \mathrm{~S} 6$ \& S10 \\
8.0 to 8.9 & Basic & $3,27.27 \%, \mathrm{~S} 8, \mathrm{~S} 9 \& \mathrm{~S} 11$ \\
More than 9.0 & Strongly basic & Nill \\
\hline
\end{tabular}

It is observed from the Table 3 that out of 11 soil samples 5 (45.45\%) sample shows moderately acidic soil which is located in valley area and topographically higher areas, while $1(0.09 \%)$ sample shows neutral in nature. Moderate basic (2 soil samples; S6 \& S10; 18.18\%) and basic (27.27\%; 3 soil samples; S8, S9 \& S11) soil was found in study area. There were no strongly acidic, acidic or strongly basic soils were found in this study area. Results were almost similar with Uddin and Islam (1998) found most soil pH ranges 2 to 8.5 of the Coastal soils of Bangladesh.

\subsubsection{Soil Electrical Conductivity (EC)}

Soil electrical conductivity (EC) is a measure of the amount of salts in soil (salinity of soil). It is an important indicator of soil health and it affects crop yields, crop suitability, plant nutrient availability, and activity of soil microorganisms which influence key soil processes including the emission of greenhouse gases such as nitrogen oxides, methane, and carbon dioxide (Smith \& Doran, 1996). Samphors, Thirapong, Tomomi, and Jiro (2015) revealed that the changes in soil EC were significantly sensitive to the ripening stages of rice planted on different 
levels of soil salinity. Following table (Table 4) shows the content of soil electrical conductivity (EC) of paddy fields in the study area.

Table 4. Classification of soil EC of the sample according to standard of SRDI, (2003); BARC, (2005) and Chowdhury et al. (2011)

\begin{tabular}{lll}
\hline Type & EC range (dS/m) & No. of Soil Samples, percentage (\%) and locations \\
\hline Low & $2.0-4.0$ & $3,27.27 \%, \mathrm{~S} 1, \mathrm{~S} 2 \&$ S3 \\
Medium & $4.1-8.0$ & $8,72.73 \%, \mathrm{~S} 4, \mathrm{~S} 5, \mathrm{~S} 6, \mathrm{~S} 7, \quad \mathrm{~S} 8, \mathrm{~S} 9, \mathrm{~S} 10$ \& S11 \\
High & $8.1-16.0$ & Nill \\
Very high & $>16$ & Nill \\
\hline
\end{tabular}

The EC values ranged from 3.10 to $7.24 \mathrm{dS} / \mathrm{m}$ in the study area. The lowest value was found in valley areas soil (S1), and highest was in $\mathrm{S} 11(7.24 \mathrm{dS} / \mathrm{m})$. In this area (S11), transpiration of salts with surface runoff is negligible. Instead evaporation of surface and groundwater at shallow depth leave behind the salts which appear as encrustation on soils. The higher values $(>4 \mathrm{dS} / \mathrm{m})$ of EC have been obtained from both valley areas and plain areas $(72.73 \%$, S4 and S5, S6, S7, S8, S9, S10 \& S11) reflecting low flushing rate and sluggish groundwater movement. The salt accumulation in the area is associated with the areas of high (shallow) water table. On the other hand, lower values of EC were recorded for upstream and topographically higher areas can be attributed to the rolling topography, relatively higher gradient, seasonal irrigation and alternating cropping pattern $(27.27 \%$, S1, S2 \& S3). About $72.73 \%$ (Table 4) soil samples were saline according to the acceptable range of Allotey, Asiamah, Dedzoe, and Nyamekye (2009); Richards (1954) and Indonesian Agency for Agricultural Research and Development, Indonesia and NSW Department of Primary Industries, Australia (2008). Almost similar findings were reported by Uddin and Islam (1998), and Patcharapreecha, Topark-Ngarm, Goto, and Kimura (1989) in different coastal agricultural saline soils.

4.1.6 Relation between Soil Texture and Soil Salinity (EC) in Paddy Fields of the Study Area

Following Figure 2 shows relation between soil texture and different soil salinity (EC) in different paddy fields.

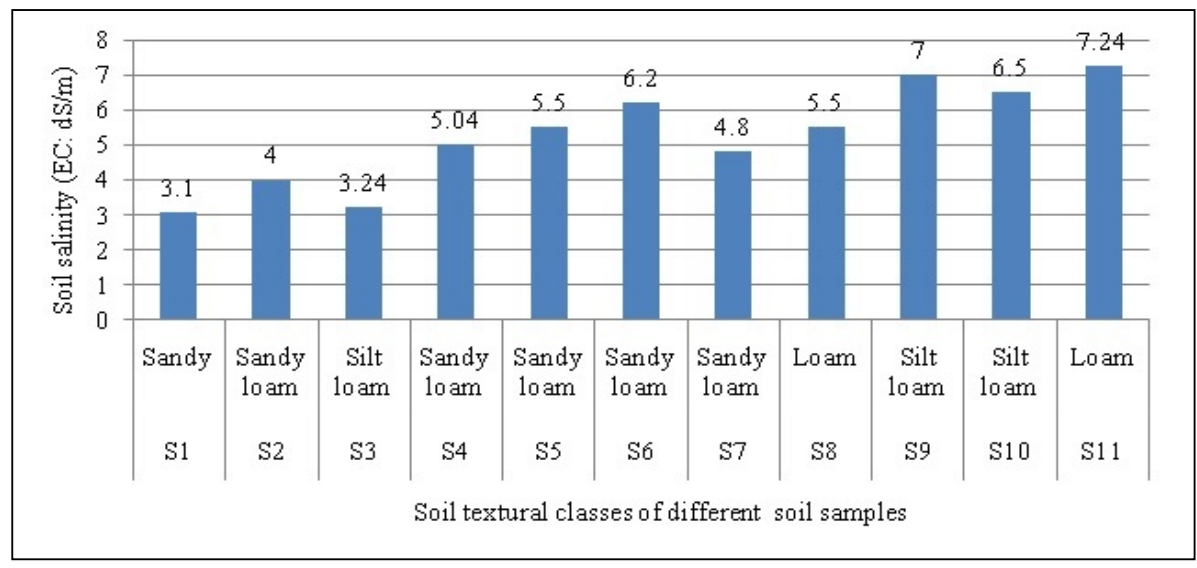

Figure 2. Soil texture with different soil salinity level in study area

Above Figure 2 shows the relationship between soil textural classes and soil salinity in different study area samples. The highest soil salinity was found $7.24 \mathrm{dS} / \mathrm{m}$ in site 11 (S11) which was loam textured soil, whereas the lowest value was found $3.10 \mathrm{dS} / \mathrm{m}$ in site 1 (S1) which was sandy texture soil (Figure 1). Rather than this value another lower salinity was found in site 3 (S3) which represents silt loam texture soil, although comparatively higher values of soil salinity were found in silty loam textured soil of site $9 \& 10$. Although S3 shows lower salinity with silty loam it may cause due to low soil $\mathrm{pH}$ (Table $1 \& 3$ ). Medium soil salinity was found in sandy loam textured soils of S2, S4, S5, S6 \& S7. It can be assumed that soil texture has profound effects on changing soil salinity of this study area. This finding is conformity with Indonesian Agency for 
Agricultural Research and Development, Indonesia and NSW Department of Primary Industries, Australia (2008).

\subsubsection{Soil Organic Matter (OM) Content (\%)}

Soil organic matter plays an important role on physical, chemical and biological properties of a soil. Organic matter is known as 'storehouse of plant nutrients' and 'life force of a soil'. A good soil should have at least $2.5 \%$ organic matter, but in Bangladesh most of the soil has less than 1.5\%, and some soil possess even less than 1\% organic matter (BARC, 2005; SRDI, 1985). According to Malaysian Agriculture Research and Development Institute [MARDI] (2000) optimum soil OM content for paddy is $3-5 \%$. Soil OM content in the study areas were low and ranged from 0.22 to $1.32 \%(M=0.75)$ in study area (Table 2$)$, which is absolutely lower than good agricultural soil OM content according to BARC, 2005 and SRDI, 1985. Lowest value of soil OM content was found in S8 (0.22\%), and highest value was found in S3 (1.32\%). This possibly caused by the effects of soil salinity (EC) in paddy field. Islam et al. (2014) found most soils had very low amounts of organic matter. A high concentration of $\mathrm{Na}^{+}$caused a highly significant depletion of $\mathrm{OM}$ in soils, creating extremely hazardous conditions in crop production, especially in low-lying areas. Uddin and Islam (1998) investigated the Coastal soils of Bangladesh and most soil Organic matter (\%) ranges $<2$ to $>20$. Patcharapreecha et al. (1989) investigated saline soils that contain $0.07-0.74 \%$ soil OM. Haque (2006) found the pretty low (1.0-1.5\%) soil OM content in coastal saline soils.

\subsubsection{Soil Nutrient Content (\%) in Different Paddy Field Soils of the Study Area}

Proper nutrition is essential for satisfactory crop growth and production. An understanding of general nutrient status can be obtained for a field if soil tests are done. The essential nutrient elements are $\mathrm{N}, \mathrm{P}, \mathrm{K}, \mathrm{Ca}, \mathrm{Mg}$, and $\mathrm{S}$. Among these nutrient elements, $\mathrm{N}$ ranks first in plant requirement and phosphorus $(\mathrm{P})$ ranks second followed by potassium (K). N, $\mathrm{P}$, and $\mathrm{K}$ are referred to essential nutrients because nearly all plants use them for growth and development Samuel and Ebenezer (2014). Soil nutrient contents (N, P, K, Ca \& Mg) in different paddy field soils of Jhilwanja Union, Cox’s Bazar, Bangladesh is given below (Table 5).

Table 5. Soil nutrient content (\%) in different paddy field soils of Jhilwanja Union, Cox's Bazar, Bangladesh

\begin{tabular}{llllll}
\hline Sample no. & Total N & Total P & Exchangeable K & Exchangeable Ca & Exchangeable Mg \\
\hline S1 & $0.12 \mathrm{a}$ & $0.01 \mathrm{e}$ & $0.20 \mathrm{~d}$ & $0.0031 \mathrm{ab}$ & $0.07 \mathrm{ef}$ \\
S2 & $0.10 \mathrm{~b}$ & $0.02 \mathrm{e}$ & $0.26 \mathrm{~cd}$ & $0.0001 \mathrm{bc}$ & $0.08 \mathrm{ef}$ \\
S3 & $0.12 \mathrm{a}$ & $0.05 \mathrm{~d}$ & $0.29 \mathrm{~cd}$ & $0.0000 \mathrm{c}$ & $0.05 \mathrm{f}$ \\
S4 & $0.09 \mathrm{~b}$ & $0.06 \mathrm{~cd}$ & $0.54 \mathrm{bc}$ & $0.0002 \mathrm{bc}$ & $0.11 \mathrm{de}$ \\
S5 & $0.07 \mathrm{c}$ & $0.06 \mathrm{~cd}$ & $0.54 \mathrm{bc}$ & $0.0002 \mathrm{bc}$ & $0.14 \mathrm{~d}$ \\
S6 & $0.07 \mathrm{c}$ & $0.10 \mathrm{a}$ & $0.72 \mathrm{~b}$ & $0.0007 \mathrm{bc}$ & $0.34 \mathrm{c}$ \\
S7 & $0.12 \mathrm{a}$ & $0.08 \mathrm{~b}$ & $0.70 \mathrm{~b}$ & $0.0002 \mathrm{bc}$ & $0.11 \mathrm{de}$ \\
S8 & $0.03 \mathrm{~d}$ & $0.08 \mathrm{~b}$ & $1.04 \mathrm{a}$ & $0.0037 \mathrm{a}$ & $0.61 \mathrm{a}$ \\
S9 & $0.06 \mathrm{c}$ & $0.08 \mathrm{~b}$ & $0.55 \mathrm{bc}$ & $0.0009 \mathrm{abc}$ & $0.51 \mathrm{~b}$ \\
S10 & $0.04 \mathrm{~d}$ & $0.09 \mathrm{ab}$ & $0.77 \mathrm{ab}$ & $0.0002 \mathrm{bc}$ & $0.31 \mathrm{c}$ \\
S11 & $0.04 \mathrm{~d}$ & $0.07 \mathrm{bc}$ & $0.64 \mathrm{~b}$ & $0.0010 \mathrm{abc}$ & $0.54 \mathrm{~b}$
\end{tabular}

Note. Figures in the same column denoted by the same letter (s) did not differ significantly according to DMRT at $\mathrm{p}<0.05$.

\section{1) Total Nitrogen (N) Content (\%)}

Nitrogen is the most limiting factor in crop production. The pale green color of N-deficient plants is the most common deficiency symptom exhibited by growing plants (Thompson \& Troeh, 1978). Optimum limit of percentage of total nitrogen $(\mathrm{N})$ is four categories such as low $(<0.180 \%)$, medium $(0.180-0.360 \%)$, high $(0.361-0.450 \%)$ and very high (> 0.45\%) (SRDI, 2003; BARC, 2005; Chowdhury, Khairun, Salequzzaman, \& Rahman, 2011). Total nitrogen (\%) content ranged from 0.03 to $0.12 \%$ in the study area (Tables 2 and 5). Highest value was found in S1, S3 \& S7 and lowest was found in S8. Soil N content was low in the study area $(M=0.08$, Table 2) according to SRDI, 2003; BARC, 2005 and Chowdhury et al. 2011. Table 5 shows statistically similar 
results in site $2 \&$ site 4 . Similar results were also appeared in S5, S6 \& S9 and with also in S8, S10 \& S11 respectively. Results also revealed that, comparatively higher $\mathrm{N}$ content were found in valley areas soils than plain areas soils except S7. It may caused by the effects of soil salinity (Sumner, 2000). Nitrogen status demarked that considering agricultural field's areas were less fertile and farmers need to use different organic and inorganic fertilizers in paddy fields. Result shows similarities with several researchers, as (Rahman, Hassan, Alam, Akid, \& Riyad, 2014; Maliwal \& Somani, 2010). Islam et al. (2014) found most soils had very low amounts of total N. Like other tropical and subtropical soils, Bangladesh soils have long been categorized as poor in soil fertility because of low N supplying capacity (Islam, 1983). Patcharapreecha et al. (1989) investigated saline soils contains total nitrogen (0.005-0.043\%) contents were very low in all the soils. Several studies have shown that salinity reduces N uptake (Al-Rawahy, Stroehlein, \& Pessarakli, 1992) by crops and do not support plant growth due to a higher osmotic pressure in the plant soil system Bhumbla (1977) despite adequate nutrient levels being available in the soil. Nitrogen availability in wetlands is sensitive to various environmental factors, including air temperature, water tables, flooding periods and soil properties (Bai, Gao, Xiao, Wang, \& Huang, 2012; Chen, Borken, Stange, \& Matzner, 2012; Ehrenfeld \& Yu, 2012).

2) Total Phosphorus (P) Content (\%)

Phosphorus $(\mathrm{P})$ is essential for plant growth and it stimulates growth of young plants, giving them a good and vigorous start. Soil phosphorus is most available for plant use at $\mathrm{pH}$ values of 6 to 7 (http://msucares.com/crops/soils/phosphorus.html). Optimum limit of percentage of total $\mathrm{P}$ is four categories such as low (<12), medium (12.1-24.00), high (24.0-30.00) and very high (> 30.0) (SRDI, 2003; BARC, 2005; Chowdhury et al., 2011). Total P content of soils varied from $0.01 \%$ (S1) to $0.10 \%$ (S6). Thus, the minimum value was obtained in valley area and the maximum value was obtained in plain area. Results also revealed that S7, S8, S9, S10 \& S11 shows statistically similar and result indicated plain area contain higher P content than valley area soils, as site of S1, S2, S3 \& S4. Thus, Content of \% of total phosphorus were very low (Tables 2 and 5) in study area according to SRDI, 2003; BARC, 2005 and Chowdhury et al. 2011 reported that $41 \%$ of the soils of Bangladesh contained P below the critical level and $35 \%$ of the soils contained P above the critical level but below the optimum level. The phosphorus content in soils depends largely on the application of fertilizers for agricultural practices and it present in soil as solid phase with varying degree of solubility. When water soluble $\mathrm{P}$ is added to the soil, it is converted very quickly to insoluble solid phase by reacting with soil constituents. These may include calcium Cate (Olsen, 1953), Fe and Al oxides (Dean \& Rubin, 1947) and partly organic matter. The added $\mathrm{P}$ is more likely to be absorbed on hydrated $\mathrm{Fe}$ and $\mathrm{Al}$ oxides or on the edge of the clay minerals in neutral to acidic range of soils (Russell, 1988). These reactions affect the availability of $\mathrm{P}$ and as a result of these reactions, a very small amount of total $\mathrm{P}$ is present in soil solution at any time reflected by soil testing. However, a low to medium range of soils available $\mathrm{P}$ under study area may be mostly affected by past fertilization, $\mathrm{pH}$, organic matter content, texture and various soil management and agronomic practices Verma, Patel, Toor, and Sharma (2005).

\section{3) Exchangeable Potassium (K) Content (\%)}

Potassium $(\mathrm{K})$ is another important nutrient, it not only important for the increase of soil fertility status but also directly involved with plant growth. Potassium is important for early growth stimulation, increasing protein production, improves the efficiency of water and improves resistance to diseases and insects. Results shows that (Tables 2 and 5) minimum $\mathrm{K}$ content was found in S1 (0.20\%) and maximum (1.04\%) in S8 with a mean of $0.57 \%$ shows $\mathrm{K}$ status of study area is high (Tables 2 and 5$)$. Potassium level $(0.20 \%$ to $1.04 \%)$ represents the considering agricultural fields were fertile and Rahman et al. (2014) found K (0.3-1.0\%) which was almost similar with this investivagation. Statistically similar results were found in S8 \& S10; S4, S5, S6, S7, S9 \& S11 and S1, S2, S3, S4, S5, S10 \& S11. Results also reveals that, there were lower K content in valley soils compared with plain areas soils (Table 5). Adequate level of available $\mathrm{K}$ in the study area may be attributed to the prevalence of K-rich clay minerals like illite and kaolinite. Farmers used different types of organic and inorganic fertilizers, especially potash fertilizer Islam, Altamash, Sarker, and Hossain (1985), and the decomposition of the minerals containing potassium, the content of total $\mathrm{K}$ was largely determined by the soil type and the mineral composition of the soils (Sharpley, 1989). However, potassium is rarely a limiting factor in saline soils Maliwal and Somani (2010).

\section{4) Exchangeable Calcium (Ca) Content (\%)}

Calcium $(\mathrm{Ca})$ is the predominant positively charged ion $\left(\mathrm{Ca}^{++}\right)$held on soil clay and organic matter particles because it is held more strongly than magnesium $\left(\mathrm{Mg}^{++}\right)$, potassium $\left(\mathrm{K}^{+}\right)$, and other exchangeable cations. Soils normally have large amounts of exchangeable calcium (300-5000 ppm). Ideal limit of percentage of total 
calcium $(\mathrm{Ca})$ is four categories such as low $(<3.0)$, medium (3.1-6.0), high (6.1-7.5) and very high $(>7.5)$ (SRDI, 2003; BARC, 2005; Chowdhury et al., 2011). Soil Ca content was too low in the paddy fields of the study area (Table 2) according SRDI, 2003; BARC, 2005 and Chowdhury et al. 2011. Result reveals that Ca varied from $0 \%$ (S8) to $0.0037 \%$ (S3) with mean value of $0.0009 \%$, respectively (Tables 2 and 5). Statistically similar results were found among all sites of study area samples (Table 5) except S3 \& S8. This lower Ca content may be due to changes in osmotic and ion-specific effects that can produce imbalances in plant nutrients, including deficiencies of several nutrients or excessive levels of $\mathrm{Na}^{+}$(Kaya, Kirnak, \& Higgs, 2001).

5) Exchangeable Magnesium (Mg) Content (\%)

Magnesium (Mg) is located both in clay minerals and associated with cation exchange sites on clay surfaces. The primary and secondary minerals are important sources of $\mathrm{Mg}$ for plant nutrition, especially in unfertilized soil. But plant-available Mg concentrations cannot be accurately predicted based only on the parent material composition due to differences in mineral weathering rates and leaching. Perfect limit of percentage of exchangeable $\mathrm{Mg}$ is four categories such as low $(<0.75)$, medium $(0.751-1.5)$, high (1.51-1.87) and very high $(>$ 1.875) (SRDI, 2003; BARC, 2005; Chowdhury et al., 2011). Mg content ranged from $0.05 \%$ (S3) to $0.61 \%$ (S8) with a mean of $(M=0.26)$ in study area sample. $\mathrm{Mg}$ content was low content in everywhere of the studied samples (Table 5) according SRDI, 2003; BARC, 2005; Chowdhury et al., 2011. Osmotic and ion-specific effects produced the imbalances in plant nutrients causing deficiencies of nutrients in soil (Kaya et al., 2001).

\subsection{Correlations and Regression between Soil Salinity (EC) and Physico-chemical Properties of Soil}

Correlations and regression between soil salinity (EC) and physico-chemical properties of field soils of Jhilwanja Union, Cox's Bazar, Bangladesh is given in Table 6.

Table 6. Correlations between soil salinity (EC) and physico-chemical properties of soil

\begin{tabular}{|c|c|c|c|c|c|c|c|c|c|c|}
\hline Physico-chemical properties & 1 & 2 & 3 & 4 & 5 & 6 & 7 & 8 & 9 & 10 \\
\hline 1 Soil pH & --- & & & & & & & & & \\
\hline 2 Soil Temperature $\left({ }^{\circ} \mathrm{C}\right)$ & $.783^{* *}$ & --- & & & & & & & & \\
\hline $3 \mathrm{EC}(\mathrm{dS} / \mathbf{m})$ & $.917^{* *}$ & $.808^{* *}$ & --- & & & & & & & \\
\hline 4 Bulk Density $\left(\mathrm{g} / \mathrm{cm}^{3}\right)$ & -.427 & -.158 & -.326 & --- & & & & & & \\
\hline $5 \mathrm{O} . \mathrm{M}(\%)$ & $-.775^{* *}$ & $-.896^{*}$ & $-.712^{*}$ & .251 & --- & & & & & \\
\hline 6 Total N (\%) & $-.875^{* *}$ & $-.809^{* *}$ & $-.830 * *$ & .500 & $.853^{* *}$ & --- & & & & \\
\hline 7 Total P (\%) & $.848^{* *}$ & $.624^{*}$ & $.762^{* *}$ & -.298 & -.480 & -.601 & --- & & & \\
\hline 8 Exchangeable K (\%) & $.808^{* *}$ & $.828^{* *}$ & $.653^{*}$ & -.291 & $-.738^{* *}$ & $-.738^{* *}$ & $.833^{* *}$ & --- & & \\
\hline 9 Exchangeable $\mathrm{Ca}(\%)$ & .115 & .289 & -.101 & .041 & -.579 & -.244 & -.159 & .250 & --- & \\
\hline 10 Exchangeable $\mathrm{Mg}(\%)$ & $.884^{* *}$ & $.800^{* *}$ & $.785^{* *}$ & -.510 & $-.879^{* *}$ & $-.870^{* *}$ & .597 & $.714^{*}$ & .435 & --- \\
\hline
\end{tabular}
Note. ${ }^{*} p=.05,{ }^{* *} p=.01$.

Table 6 shows that soil salinity (EC) is significantly positively correlated with soil $\mathrm{pH}(r=.917)$, soil temperature $(r=.808)$, total $\mathrm{P}$ content $(r=.762)$, exchangeable $\mathrm{K}(r=.653)$ and exchangeable $\mathrm{Mg}(r=.785)$. Moreover, soil salinity (EC) is negatively correlated with soil OM $(r=-.712)$ and total $\mathrm{N}(r=-.830)$. Neither bulk density nor exchangeable Ca content was significantly associated with soil salinity (EC). These results were in confirmatory with the results reported by several researchers (e.g. Rhoades, Chanduvi, \& Lesch, 1999; Pan, Zhao, Zhao, Han, \& Wang, 2013; Eltaib, 2003). 


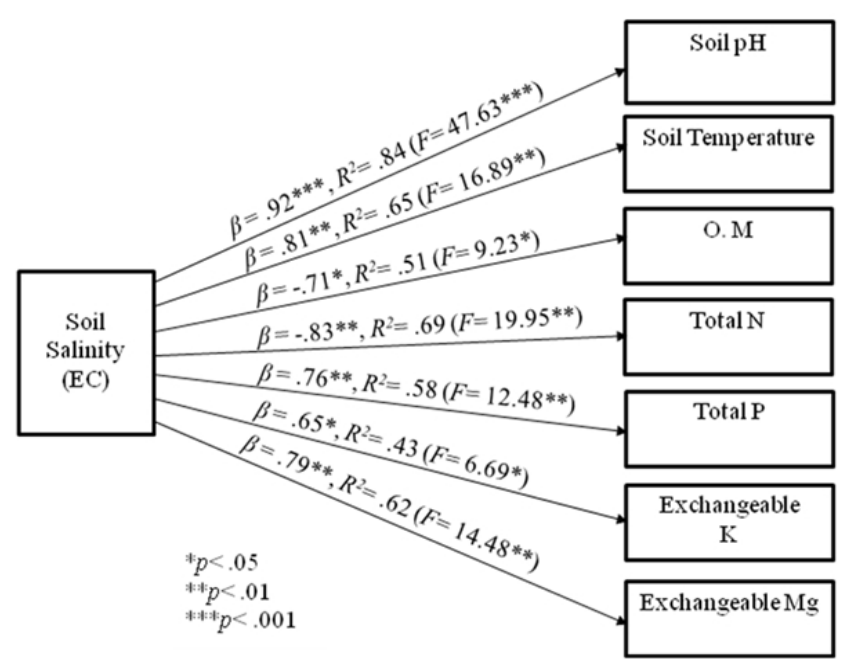

Figure 3. Effects of soil salinity (EC) on soil pH, soil temperature, O.M, total N, total P, exchangeable K, and exchangeable $\mathrm{Mg}$

We performed simple regression analysis to investigate the contribution of soil salinity (EC) on soil $\mathrm{pH}$, soil temperature, O.M, total N, total $\mathrm{P}$, exchangeable $\mathrm{K}$, and exchangeable Mg. Results of analyses are displayed in Figure 3. There, one can see that soil salinity (EC) had a significant contribution to soil $\mathrm{pH}(\beta=.92, t=6.90, p$ $<.001$ ), which reveals that 1 unit increase in soil salinity (EC) increases .92 unit in soil pH. Moreover, $\mathrm{R}^{2}$ value indicates that soil salinity can explain approximately $84 \%$ variability in soil $\mathrm{pH}$. Figure 2 also indicates that soil salinity (EC) was a significant predictor variable of soil temperature $(\beta=.81, t=4.12, p<.01)$ as well as O.M $(\beta$ $=-.71, t=-3.04, p<.05$ ), which reveals that 1 unit increase in soil salinity (EC) increases .81 unit in soil temperature and .71 unit decrease in O.M. Furthermore, approximately $65 \%$ variability in soil temperature and approximately $51 \%$ variability in O.M could be explained by soil salinity. Total $\mathrm{N}$, total $\mathrm{P}$, exchangeable $\mathrm{K}$ and exchangeable $\mathrm{Mg}$ also depend on soil salinity. Because soil salinity significantly contribute to total $\mathrm{N}(\beta=-.83, t$ $=-4.47, p<.01)$, total $\mathrm{P}(\beta=.76, t=3.53, p<.01)$, exchangeable $\mathrm{K}(\beta=.65, t=2.59, p<.05)$ and exchangeable Mg. $(\beta=.79, t=3.81, p<.01)$ which reveals that 1 unit increase in soil salinity (EC) decreases .83 unit in total $\mathrm{N}, .76, .65$ and .79 unit increase in total $\mathrm{P}$, exchangeable $\mathrm{K}$ and exchangeable Mg respectively. In addition, there was variance of $58 \%, 43 \%$, and $62 \%$ in total $\mathrm{P}$, total $\mathrm{N}$, exchangeable $\mathrm{K}$ and exchangeable $\mathrm{Mg}$ respectively due to variations in soil salinity (EC).

\section{Conclusion}

Coastal paddy field soils of Jhilwanja Union of Cox's Bazar district of Bangladesh is characterized under moderately acidic to basic in soil reaction, soil salinity (EC) content comes under low to medium range. The organic matter level exhibited absolutely lower than good agricultural soil. The soils of this area showed low concentrations of total $\mathrm{N}$, in total $\mathrm{P}$ content, exchangeable $\mathrm{Ca}$, low content of exchangeable $\mathrm{Mg}$ and high level of exchangeable K. In this investigation there was small sample size so, the findings should need to consider cautiously. If potential investigators take more samples for such types of research it will be a better option for generalizing the research findings. Due to laboratory limitation we used electrical conductivity to determine the intensity of soil salinity. However, exchangeable $\mathrm{Na}^{+}$and $\mathrm{Cl}^{-}$can also be suggested for accurate salinity assessment. Many environmental factors worked on soil properties, if future investigators take soil samples from study site and set an experiment in a greenhouse and observe different effects on rice performance it will be a better effort for controlling these factors. So, soils require attention regarding integrated nutrient management approaches and regular monitoring of soil health for better crop productivity and sustainable agriculture associated with applying integrated coastal zone management to ensure the food security for future generation.

\section{References}

Abedin, M. Z. (2010). Global warming, climate change and impact on agriculture in Bangladesh. $4^{\text {th }}$ National Convention of Krishibid Institute, Bangladesh.

Ahmed, A. (2011). Some of the major environmental problems relating to land use changes in the coastal areas of Bangladesh: A review. Journal of Geography and Regional Planning, 4, 1-8. 
Ali, A. M. S. (2005). Rice to shrimp: Land use/land cover changes and soil degradation in southwestern Bangladesh. Land Use Policy, 23(4), 421-435. http://dx.doi.org/10.1016/j.landusepol.2005.02.001

Allison, L. E. (1965). Organic carbon. In C. A. Black et al. (Eds.), Method of soil analysis part 1 (Am. Soc. Agronomy 9, pp. 1367-1378).

Allotey, D. F. K., Asiamah, R. D., Dedzoe, C. D., \& Nyamekye, A. L. (2009). Physico-chemical properties of three salt-affected soils in the lower Volta Basin and management strategies for their sustainable utilization. West African Journal of Applied Ecology, 12(1), 1-14. http://dx.doi.org/10.4314/wajae.v12i1.45776

Al-Rawahy, S. A., Stroehlein, J. L., \& Pessarakli, M. (1992). Dry matter yield and nitrogen-15, $\mathrm{Na}^{+} \mathrm{Cl}^{-}$and $\mathrm{K}^{+}$ content of tomatoes under sodium chloride stress. J. Plant Nutr, 15(3), 341-358. http://dx.doi.org/10.1080/01904169209364323

Aubertin, G. M., \& Kardos, L. T. (1965). Root growth through porous media under controlled conditions: I. Effect of pore size and rigidity. Soil Science of America Proceedings, 29(3), 290-293. http://dx.doi.org/10.2136/sssaj1965.03615995002900030020x

Bai, J. H., Gao, H. F., Xiao, R., Wang, J. J., \& Huang, C. (2012). A review of soil nitrogen mineralization as affected by water and salt in coastal wetlands: issues and methods. Clean-Soil Air Water, 40(10), 1099-1105. http://dx.doi.org/10.1002/clen.201200055

Bangladesh Agricultural Research Council (BARC). (2005). Fertilizer recommendation guide.

Bangladesh Bureau of Statistics (BBS). (2001). Statistical year book of Bangladesh. Government of the people's republic of Bangladesh, Dhaka.

Bangladesh Bureau of Statistics (BBS). (2003). Population census 2001. Retrieved April 12, 2012, from $\mathrm{http}: / /$ www.bbs.gov.bd/PageWebMenuContent.aspx?MenuKey=57

Bangladesh Bureau of Statistics (BBS). (2013). Statistical year book of Bangladesh. Planning division, Ministry of planning, Government of the people's republic of Bangladesh, Dhaka.

Basak, J. K., Ali, M. A., Islam, M. N., \& Alam, M. J. B. (2009). Assessment of the effect of climate change on boro rice production in Bangladesh using CERES-Rice model. Proceedings of the international conference on climate change impacts and adaptation strategies for Bangladesh (pp. 103-113).

Bhumbla, D. R. (1977). Alkali and saline soils of India (pp. 14-19). Proc. Indo-Hungarian sem. Management of salt-affected soils, Karnal, India.

Brady, N. C., \& Weil, R. R. (2004). The nature and properties of soils (13th ed.). Singapore: Pearson Education.

Cao, C., Jiang, S., Ying, Z., Zhang, F., \& Han, X. (2011). Spatial variability of soil nutrients and microbiological properties after the establishment of leguminous shrub Caragana microphylla Lam. Plantation on sand dune in the Horqin sandy land of northeast China. Ecological Engineering, 37(10), 1467-1475. http://dx.doi.org/10.1016/j.ecoleng.2011.03.012

Chaudhari, P. R., Ahire, D.V., Ahire, V. D., Chakravarty, M., \& Maity, S. (2013). Soil bulk density as related to soil texture, organic matter content and available total nutrients of Coimbatore soil. International Journal of Scientific and Research Publicatios, 3(2), 1-8.

Chen, Y. T., Borken, W., Stange, C. F., \& Matzner, E. (2012). Dynamics of nitrogen and carbon mineralization in a fen soil following water table fluctuations. Wetlands, 32(3), 57-587. http://dx.doi.org/10.1007/s13157-012-0295-7

Chintala, R., Mollinedo, J., Schumacher, T. E., Malo, D. D., \& Julson, J. L. (2014b). Effect of biochars on chemical properties of acidic soil. Archives of Agronomy and Soil Science, 60(3), 393-404. http://dx.doi.org/10.1080/03650340.2013.789870

Chintala, R., Schumacher, T. E., McDonald, L. M., Clay, D. E., Malo, D. D., Clay, S. A., ... Julson, J. L. (2014a). Phosphorus sorption and availability in biochars and soil biochar mixtures. CLEAN-Soil Air Water, 42(5), 626-634. http://dx.doi.org/10.1002/clen.201300089

Chowdhury, M. A., Khairun, Y., Salequzzaman, M., \& Rahman, M. M. (2011). Effect of combined shrimp and rice farming on water and soil quality in Bangladesh. Aquacult. Int., 19(6), 1193-1206. http://dx.doi.org/10. 1007/s10499.011.9433.0

Day, P. (1965). Particle fractionation and particle-size analysis. In C. A. Black (Ed.), Methods of Soil Analysis Part 1 (Number 9 Agronomy Series). Amer. Sot. of Agron., Inc., Madison, Wise. 
Dean, L. A., \& Rubin, E. J. (1947). Anion Exchange in Soils. Exchangeable phosphorous and anion exchange capacity. Soil Sci, 63(5), 377-388. http://dx.doi.org/10.1097/00010694-194705000-00005

District Statistics. (2011). Cox's Bazar, Bangladesh Bureau of Statistics (BBS). Statistics and informatics division. Ministry of planning, Government of the people's republic of Bangladesh.

Ehrenfeld, J. G., \& Yu, S. (2012). Patterns of nitrogen mineralization in wetlands of the New Jersey pinelands along a shallow water table gradient. Am Midl Nat, 167(2), $322-335$. http://dx.doi.org/10.1674/0003-0031-167.2.322

Eltaib, S. M. (2003). Spatial Variability of Nutrients, Electrical Conductivity and Yield and Site Specific Fertilizers Management in a Paddy Field (The Ph.D. Thesis). Faculty of Engineering, Universiti Putra Malaysia.

Hanson, W. C. (1950). The photometric determination of phosphorus in fertilizers using the phosphovanado-molybdate complex. J. Sci. Food Agric., 1(6), 172-173. http://dx.doi.org/10.1002/jsfa.2740 010604

Haque, S. A. (2006). Salinity problems and crop production in coastal regions of Bangladesh. Pakistan Journal of Botany, 38(5), 1359-1365.

Hesse, P. R. (1971). A text book of soil chemical analysis. London, John Murry Publ.

Hoque, M. A., Saika, U., Sarder, B. C., \& Biswas, K. K. (2013). Environmental and socio-economic impacts of salinity intrusion in the coastal area: A case study on Munshigong Union, Shymnagor, Satkhira. Jahangirnagar University Environmental Bulletin, 2(0), 41- 49. http://dx.doi.org/10.3329/jueb.v2i0.16329

Hossain, M. A. (2009). Global warming induced sea level rise on soil, land and crop production loss in Bangladesh. SRDI, Ministry of Agriculture, Dhaka, Bangladesh. Retrieved from http://msucares.com/crops/soils/phosphorus.html

Ikehashi, H., \& Ponnamperuma, F. N. (1978). Varietal tolerance to rice for adverse soils. Soils and Rice (pp. 801-822). IRRI, Manila, Philippines.

Indonesian Agency for Agricultural Research and Development, Indonesia and NSW Department of Primary Industries, Australia. (2008). A practical guide to restoring agriculture after a tsunami. Soil salinity (Chapter 5). Retrived from http://www.dpi.nsw.gov.au/_data/assets/pdf_file/0010/254863/A-practical-guide-to-resto ring-agriculture-after-a-tsunami.pdf

Islam, K. K., Anusontpornperm, S., Kheoruenromne, I., \& Thanachit, S. (2014). Relationship between Carbon sequestration and physico-chemical properties of soils in salt-affected areas, Northeast Thailand. Kasetsart J. (Nat. Sci.), 48, 560-576.

Islam, M. S. (1983). Soil management in agricultural research in Bangladesh (pp. 105-109). Bangladesh Agricultural Research Council, Dhaka, Bangladesh.

Islam, M. S., Altamash, S., Sarker, N. I., \& Hossain, K. M. (1985). Potassium responses in greenhouse and field studies in Bangladesh. Proceedings of the International Symposium on Potassium in Agricultural Soils (pp. 70-89). Soil Science Society of Bangladesh and Bangladesh Agricultural Research Council.

Islam, M. S., Razzaque, M. A., Rahman, M. M., \& Karim, N. H. (2004). Present and future of agricultural research in Bangladesh (in Bangla). Agriculture in the $21^{\text {st }}$ Century: challenges and possibilitie (pp. 20-27). Ministry of Agriculture, Dhaka, Bangladesh.

Jackson, M. L. (1962). Soil chemical analysis (p. 498). New York: Prentice-Hall Inc.

Jackson, M. L. (1973). Soil chemical analysis (p. 498). Prentice Hall of India Pvt. Ltd., New Delhi.

Kahlown, M. A., \& Azam, M. (2003). Effect of saline drainage effluent on soil health and crop yield. Agricultural Water Management, 62(2), 127-138. http://dx.doi.org/10.1016/s0378-3774(03)00096-9

Karim, Z., Hossain, S. G., \& Ahmed, M. (1990). Salinity problems and crop intensification in the coastal regions of Bangladesh (p. 63).

Kaya, C., Kirnak, H., \& Higgs, D. (2001). Enhancement of growth and normal growth parameters by foliar application of potassium and phosphorus in tomato cultivars grown at high $(\mathrm{NaCl})$ salinity. Journal of Plant Nutrition, 24(2), 357-367. http://dx.doi.org/10.1081/pln-100001394

Khush, G. S. (2005). What it will take to feed 5.0 billion rice consumers in 2030. Plant Molecular Biology, 59(1), 1-6. http://dx.doi.org/10.1007/s11103-005-2159-5 
Kitson, R., \& Mellon, M., (1944). Colorimetric determination of phosphorus as molybdivanadophosphoric acid. Industrial \& Engineering Chemistry Analytical Edition, 16(6), $379-383$. http://dx.doi.org/10.1021/i560130a017

Krishnan, P., Ramakrishnan, B., Reddy, K. R., \& Reddy, V. R. (2011). High-temperature effects on Rice growth, yield, and grain quality. Advances in Agronomy, 111, 87-206. http://dx.doi.org/10.1016/b978-0-12-387689-8 .00004-7

Liang, Y., Si, J., Nikolic, M., Peng, Y., \& Chen, W. (2005). Organic manure stimulates biological activity and barley growth in soil subject to secondary salinization. Soil Biol Biochem, 37(6), 1185-1195. http://dx.doi.org/10.1016/j.soilbio.2004.11.017

Local Government Engineering Department (LGED). (2003). Peoples republic of Bangladesh, Dhaka, Bangladesh.

Malaysian Agriculture Research and Development Institute (MARDI). (2000). Requirement of Rice after two decades double cropping in Malaysia. In proceedings of international symposium on Paddy soils (pp. 283-289). Nanjing, China.

Maliwal, G. L., \& Somani, L. L. (2010). Nature properties and management of saline and alkali soils. Agrotech publishing academy, India.

Moradi, F., \& Ismail, A. M. (2007). Responses of photosynthesis, chlorophyll fluorescence and ROS-scavenging systems to salt stress during seedling and reproductive stages in Rice. Annals of Botany, 99(6), 1161-1173. http://dx.doi.org/10.1093/aob/mcm052

Municipal Manuel. (2013). Cox's Bazar municipality, Cox’s Bazar. Bangladesh.

Munns, R., \& Tester, M. (2008). Mechanisms of salinity tolerance. Annu. Rev. Plant Biol, 59(1), 651-681. http://dx.doi.org/10.1146/annurev.arplant.59.032607.092911

Murtaza, G., Ghafoor, A., \& Qadir, M. (2006). Irrigation and soil management strategies for using saline-sodic water in a cotton-wheat rotation. Agri. Water Management, 81(1-2), 98-114. http://dx.doi.org/10.1016/j.agwat.2005.03.003

Olsen, S. R. (1953). Inorganic phosphorous in alkaline and calcareous soils. In W. H. Pierre \& A. G. Norman (Eds.), Soil and Fertilizer Phosphorous (Agronomy 4, pp. 81-122). Ame. Soc. Agron. Madison Wis.

Olsen, S. R., \& Sommers, L. E. (1982). Phosphorus. In A. L. Page \& R. H. Miller (Eds.), Methods of soil analysis, Part 2 (2nd ed., Agronomy Monograph 9, pp. 403-430). ASA and SSSA, Madison, WI.

Page, A. L., Miller, R. H., \& Keeney, D. R. (1982). Methods of soil analysis, Part 2, Chemical and microbiological properties (2nd ed., p. 1159). Madison, Wisconsin: American Society of Agronomy and Soil Science.

Pan, C., Zhao, H., Zhao, X., Han, H., \& Wang, Y. (2013). Biophysical properties as determinants for soil organic carbon and total nitrogen in grassland salinization. PLoS ONE, 8(1), e54827. http://dx.doi.org/10.1371/journal.pone.0054827

Patcharapreecha, P., Topark-Ngarm, B., Goto, I., \& Kimura, M. (1989). Studies on saline soils in Khon Kaen region, northeast Thailand I. Physical and chemical properties of saline soils. Soil Science and Plant Nutrition, 35(2), 171-179. http://dx.doi.org/10.1080/00380768.1989.10434751

Petersen, L. (2002). Analytical methods: soil, water, plant material, fertilizer. Soil resource management and analytical services. Soil Resource Development Institute, DANIDA, KAMPSAX, Dhaka.

Qadir, M., Oster, J. D., Schubert, S., Noble, A. D., \& Sahrawat, K. L. (2007). Phytoremediation of sodic and saline-sodic soils. Advances in Agronomy, 96, 197-247. http://dx.doi.org/10.1016/s0065-2113(07)96006-X

Rahman, M. A., Hassan, K. M., Alam, M., Akid, A. S. M., \& Riyad, A. S. M. (2014). Effects of salinity on land fertility in coastal areas of Bangladesh. International Journal of Renewable Energy and Environmental Engineering, 2(3), 174-179.

Rahman, M. M., \& Ahsan, M. (2001). Salinity constraints and agricultural productivity in coastal saline area of Bangladesh (pp. 1-14). Soil resources in Bangladesh: Assessment and Utilization.

Rhoades, J. D. (1982). Soluble salts. In A. L. Page, R. H. Miller, \& D. R. Keeny (Eds.), Methods of soil analysis, Part 2, Chemical and microbiological properties (pp. 167-17). American Society of Agronomy and Soil Science Society of America, Inc., Madison. 
Rhoades, J. D., Chanduvi, F., \& Lesch, S. (1999). Food and agricultural organization of the UN. Soil salinity assessment: Methods and interpretation of electrical conductivity measurements. FAO Irrigation and Drainage, Paper No. 57.

Richards, L. (1954). Diagnosis and improvement of saline and alkali soils. In L. A. Richards (Ed.), USA Department of Agriculture Handbook 60 (pp. 98-105). Washington, DC: US Government Printing Office. http://dx.doi.org/10.1097/00010694-195408000-00012

Russel, E.W. (1988). Recent advances in chickpea agronomy. Proceeding of the International Workshop on Chickpea Improvement (pp. 89-96). 28 Feb-2 March, 1979, ICRISAT Centre, India. Patancheru, A. P. 502 324, India.

Samphors, T., Thirapong, P., Tomomi, T., \& Jiro, T. (2015). The relationships between electrical conductivity of soil and reflectance of canopy, grain, and leaf of rice in northeastern Thailand. International Journal of Remote Sensing, 36(4), 1136-1166. http://dx.doi.org/10.1080/01431161.2015.1007254

Samuel, A. L., \& Ebenezer, A. O. (2014). Mineralization rates of soil forms of nitrogen, phosphorus, and potassium as affected by organomineral fertilizer in sandy loam. Advances in Agriculture, 2014, 5. http://dx.doi.org/10.1155/2014/149209

Saxton, K. E., Rawls, W. J., Romberger, J. S., \& Papendick, R. I. (1986). Estimating generalized soil-water characteristics from texture. Soil Sci Soc Am J, 50(4), 1031-1036. http://dx.doi.org/10.2136/sssaj1986.03615 995005000040039x

Sharpley, A. N. (1989). Relationship between soil potassium forms and mineralogy. Soil Science Society of America Journal, 53(4), 1023. http://dx.doi.org/10.2136/sssaj1989.03615995005300040006x

Shukla, R. S., \& Chandel, P. S. (2000). Plant ecology and soil science. Rajenrda Ravindra Printers (Pvt.) Ltd, Ram Nagar, New Delhi-110055.

Smith, J. L., \& Doran, J. W. (1996). Measurement and use of pH and electrical conductivity for soil quality analysis. In J. W. Doran \& A. J. Jones (Eds.). Methods for assessing soil quality (pp. 169-185). Soil Science Society of America Spec. Publ. 49. SSSA, Madison, WI. http://dx.doi.org/10.2136/sssaspecpub49.c10

Soil Resource Development Institute (SRDI). (1985). Land and Soil Resource Utilization Guide (Vol. 91, No. 18). Khulna-Barishal-Chittagong Division.

Soil Resource Development Institute (SRDI). (2003). Soil salinity in Bangladesh. Ministry of Agriculture, Dhaka, Bangladesh.

Soil Resource Development Institute (SRDI). (2010). Saline Soils of Bangladesh. Ministry of Agriculture, Dhaka, Bangladesh.

Soil Survey Staff. (1951). Soil survey manual. USDA, SCS, Agric. Handb. 18. U.S. Gov. Print. Office, Washington, DC.

Sumner, M. (2000). Handbook of soil science (p. 2148). Boca Raton: CRC Press.

Tanji, K. K. (2002). Salinity in the Soil Environment. Salinity: Environment - plants - molecules (pp. 21-51). Kluwer Academic, Dordrecht, The Netherlands. http://dx.doi.org/10.1007/0-306-48155-3_2

Thompson, L. M., \& Troeh, F. R. (1978). Soils and soil fertility. McGraw-Hill Pub., New York, USA.

Uddin, M. M. M., \& Islam, M. S. (1998). Current status, problems and management of the coastal soils of Bangladesh. Proceedings of the national Seminar on Coastal Environment and Energy Resources in Bangladesh. Khulna. Bangladesh.

United Nations Office for Project Services (UNOPS). (2008). Disaster early warning system for Cox's Bazar. Prepared by United Nations Office for Project Services (UNOPS) through Comprehensive Disaster Management Programme (CDMP) under the Ministry of Food and Disaster Management, Government of the People's Republic of Bangladesh.

Velayutham, M., Sarkar, D., Natarajan, A., Krishnan, P., Shiva Prasad, C. R., Challa, O., ... Bhattacharyya, T. (1999). Soil resources and their potentialities in coastal area of India. J. Indian Soc. Coastal Agric. Res, 17(1\&2), 29-47.

Verma, V. K., Patel, L. B., Toor, G. S., \& Sharma, P. K. (2005). Spatial distribution of macronutrients in soils of arid tract of Punjab, India. In. J. Agric. \& Biology, 7(2), 370-372.

Walkley, A., \& Black, I. A. (1934). An examination of Degtjareff method for determining soil organic matter, and 
a proposed modification of the chromic acid titration method. Soil Science, 37(1), 29-38. http://dx.doi.org/10.1097/ 00010694-193401000-00003

Wang, Q. Z., Wu, C. H., Xie, B., Liu, Y., \& Cui, J. (2012). Model analysing the antioxidant responses of leaves and roots of switchgrass to NaCl-salinity stress. Plant Physiol Biochem, 58, 288-296. http://dx.doi.org/10.1016/j.plaphy.2012.06.021

Zeng, L., \& Shannon, M. C. (2000). Salinity effects on seedling growth and yield components of rice. Crop Science, 40(4), 996-1003. http://dx.doi.org/10.2135/cropsci2000.404996x

\section{Copyrights}

Copyright for this article is retained by the author(s), with first publication rights granted to the journal.

This is an open-access article distributed under the terms and conditions of the Creative Commons Attribution license (http://creativecommons.org/licenses/by/3.0/). 